\title{
Calicinal trichomes of Adenocalymma magnificum (Bignoniaceae) producing lipophilic substances: ultrastructural and functional aspects
}

\author{
Thália do Socorro Serra Gama ${ }^{1}$, Diego Demarco ${ }^{1} \&$ Ana Cristina Andrade de Aguiar-Dias ${ }^{2}$ \\ 1. University of São Paulo, Institute of Biosciences, Rua do Matão, 05508-090, P.O. Box 277, São Paulo, SP, Brazil; \\ thaliagama@gmail.com,diegodemarco@usp.br \\ 2. Federal University of Pará, Institute of Biological Sciences, 66075-110, P.O. Box 479, Belém, PA, Brazil; \\ acaaguiar@yahoo.com.br
}

\section{Received 04-IX-2014. Corrected 10-XII-2014. Accepted 23-I-2015.}

\begin{abstract}
Plant structures that secrete lipids and phenolic compounds are often associated with the protection and development of organs against desiccation, in addition to the protection they provide against animals, as the capitate trichomes of Adenocalymma magnificum. Understanding the glandular activities that occur in these trichomes has required the study of their ontogeny, structure, ultrastructure and histochemical aspects; the interpretation of their ecological functions or evolutionary history is complicated by the scarcity of reports on calicinal trichomes that are not nectar-secreting. Samples of floral calyx in anthesis and flower buds at different stages of development were fixed and processed according to the methods for light and electron microscopy. The trichomes are randomly distributed throughout the entire inner surface of the calyx and are also visible on the flower buds. These capitate glandular trichomes were composed of a peduncle, having up to nine cells, and a multicellular secretory head with their cells in columnar format and arranged in disc form. The collar cell, which is under the secretory head, divides anticlinally and arranges itself side by side with the mother cell. As they develop, they bend with some of them becoming adpressed to the calyx. Histochemical tests indicate that the secretory head cells produce lipid substances, acidic lipids and phenolic compounds. In the secretory head, the vacuome is dispersed and the cytoplasm possesses a great number of smooth endoplasmic reticulum and leucoplasts, organelles involved in the production of osmiophilic substances. In some regions of the secretory cells, cuticle detachment was observed; however, the accumulation of secretions was not observed. This study describes, for the first time, the origin, development, and secretion process of the calicinal trichomes of Adenocalymma magnificum, showing that production of lipophilic substances is important for this plant, possibly the trichomes may be involved in the plant's chemical defense against insects, offering protection against herbivores. Rev. Biol. Trop. 63 (2): 537-544. Epub 2015 June 01.
\end{abstract}

Key words: Adenocalymma, capitate trichomes, granulocrine secretion, lipids, phenolic compounds.

The secretory structures are defined as specialized isolated cells or multicellular structures of different forms, which secrete specific substances (Fahn, 1979, 2000) and are important in the species delimitation in Bignoniaceae (Seibert, 1948). Ontogenetic studies exist that clarify the development process in addition to offering information to explain the synthesis and secretion of the compounds produced by these structures (Ascensão, \& Pais, 1987; Moura, Isaias, \& Soares, 2005; Silva, \& Machado, 1999).
The anatomy of the secretory trichomes present in the calyx of Bignoniaceae species has been studied by several researchers (Rivera, 2000a, 2000b; Subramanian, \& Inamdar, 1985; Subramanian, \& Inamdar, 1989). However, the focuses of these studies were the calycinal nectaries; little has been written about the functional aspects, structural organization and secretion present in the other secretory structures.

These secretory structures contained in the calyx have been related to the attraction 
or reward for pollinators, to the chemical or mechanical protection against herbivores, or to the flower for protection against desiccation and several other abiotic factors (Bottega, \& Corsi, 2000; Castro, Vega, \& Múlgura, 2001; Simões, Castro, \& Kinoshita, 2006).

Adenocalymma magnificum Mart. ex DC. is a liana with large flowers and an attractive corolla that has extrafloral nectaries as well as peltate and capitate trichomes (Solereder, 1908). Regarding the latter, there is a shortage of information, especially with respect to the anatomical and ultrastructural aspects, making the interpretation of the ecological function difficult. With this in mind, the present study investigated the development and functional aspects of the glandular trichomes of the inner calyx surface of $A$. magnificum.

\section{MATERIAL AND METHODS}

A. magnificum Mart. ex DC. fresh samples of three flower calyx in anthesis and flower buds specimens at different development stages, were randomly chosen and collected between May and July of 2011 and 2012 (with average rainfall of $224.5 \mathrm{~mm}$ and $145.35 \mathrm{~mm}$, respectively per year). The plants were located and obtained from along the roadsides of Marudá city (PA-318), under this coordinates $00^{\circ} 42^{\prime} 42^{\prime \prime} \mathrm{S}-47^{\circ} 41^{\prime} 45^{\prime}$ ' WGr, in the state of Pará, Brazil. Voucher specimens were prepared and deposited in the herbarium João Murça Pires (MG 203513).

For the anatomical analysis using light microscopy, all the samples were fixed in FAA and neutral-buffered formalin for 24 and 48 hours respectively, dehydrated in an ethanol series and embedded in Paraplast (Leica Microsystems Inc., Heidelberg, Germany). Cross and longitudinal sections $(8-13 \mu \mathrm{m})$ were made using a rotary microtome and subsequently stained in Safranin and Astra Blue (Gerlach, 1984). The following histochemical tests were carried out: PAS reaction for total polysaccharides (McManus, 1948), Sudan black B for total lipids (Pearse, 1980), ferric chloride for phenolic compounds (Johansen, 1940), and Nile blue
A, for neutral and acidic lipids (Cain, 1947). Standard control procedures were carried out simultaneously for all histochemical tests.

The material designated for transmission electron microscopy (TEM) analysis was fixed in $2.5 \%$ glutaraldehyde for 24 hours, postfixed in $1 \%$ osmium tetroxide in $0.1 \mathrm{M}$ phosphate buffer, $\mathrm{pH}$ 7.2, dehydrated in an acetone-solution series and embedded in Spurr resin (Roland, 1978). Ultrathin sections were made and counterstained with uranyl acetate (Hayat, 1972) and lead citrate (Reynolds, 1963) for further analysis on a Zeiss EM 900 electron microscope.

The samples for scanning electron microscopy (SEM) analysis were fixed in $2.5 \%$ glutaraldehyde for 24 hours, post fixed in $1 \%$ osmium tetroxide in $0.1 \mathrm{M}$ phosphate buffer, $\mathrm{pH}$ 7.2, dehydrated in ethanol series up to $100 \%$ and critical point drying (Robards, 1978). The dried material was placed on aluminum stubs, sputter-coated with a thin gold layer and examined in a LEO 1450 VP electron microscope.

\section{RESULTS}

Distribution and ontogeny: The $A$. magnificum trichomes are capitate glandular (Fig. 1A), characterized by a long peduncle composed of two to nine cells, including two apical cells (collar cells), and a multicellular secretory head, composed of up to 10 columnar-shaped cells, arranged in a disk. These trichomes are randomly distributed, occupying a large inner surface area of the calyx along its entire length (Fig. 1B) and is also visible on the flower buds.

The capitate trichome originates from the protodermis on the adaxial face of the calyx. The trichome precursor cell is larger than the adjacent ones, whose projection is slightly lateral with a spherical nucleus (Fig. 1C). Initially, this cell increases in volume and later undergoes a periclinal division (Fig. 1D), becoming a bicellular structure, formed by a peduncle cell and a conical apical cell, where it undergoes successive periclinal divisions (Fig. 1E). It is composed of a uniseriate row of nine cells (Fig. 1F), which corresponds to eight cells of 

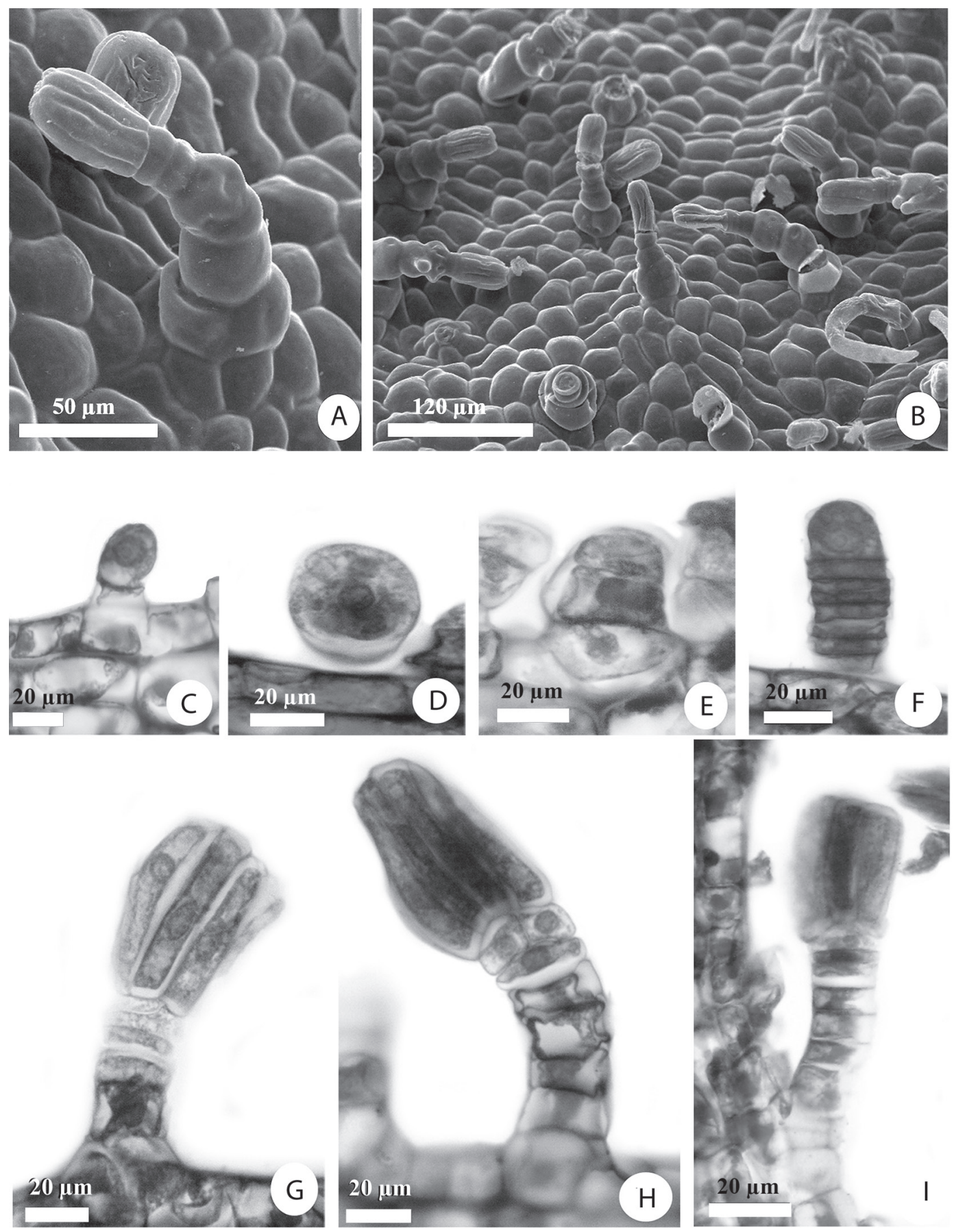

Fig. 1. Structure and development of Adenocalymma magnificum capitate glandular trichome. A. Final structure of the capitate glandular trichome in SEM. B. Distribution of the trichomes in the calyx inner surface. C - I. Capitate glandular trichome development. C. Precursor cell with lateral projection. D. First periclinal division. E. Successive periclinal divisions. F. Uniseriate row. G. Collar cell evidencing the anticlinal division. H. Peduncle apical cells side by side (collar cells). I. Capitate glandular trichome adpressed. 
the peduncle and the initial cell of the secretory head. This apical cell passes through several anticlinal divisions, which extends forming a columnar multiseriate secretory head, containing up to 10 columnar cells arranged in a disk. After this stage, the collar cell, which is under the secretory head, divides anticlinally (Fig. 1G) and arranges itself side by side with the mother cell (Fig. 1H). As they develop, they will bend, with some of them becoming adpressed to the calyx (Fig. 1B-I).

Secretion and ultrastructure: Histochemical tests indicated that the secretory head cells produce lipid substances (Fig. 2A) and acidic lipids on the secretory head (Fig. 2B); phenolic compounds (Fig. 2C) were also detected.

The peduncle cells (Fig. 3A and Fig. 3B) have thick anticlinal walls, with the two apical cells (collar cells) thicker when compared to the others. The cytoplasm of these cells is sparse and has electron dense droplets, constituted of lipophilic phenolic compounds.

In the secretory cells of the trichome head, the vacuome is dispersed (Fig. 3C) and the cytoplasm possesses a prominent smooth endoplasmic reticulum, several leucoplasts and mitochondria (Fig. 3D).

The leucoplasts are present in large quantities in the secretory cells and possess varied shapes with a reduced inner membrane system (Fig. 3E). In the stroma, there are osmiophilic drops that are usually partially or totally surrounded by the periplastidial endoplasmic reticulum (Fig. 3D). Smooth endoplasmic reticulum was strictly associated with such lipophilic substances, producing phenolic compounds (Fig. 3F).

During this secretory stage, the cells exhibit vesicles located near the plasma membrane. Therefore, the secretion process is merocrine and the extrusion is probably carried out through these vesicles (Fig. 3E), which transport these compounds from the inside of the cell to its periphery, where the vesicle membrane possibly merges with the plasma membrane. When this occurs, the periplasmic content will cross the cell wall (Fig. 3G), reaching the cuticle and continuing past the external side and reveals the granulocrine release. In some regions of the secretory cells cuticle detachment was observed; however, the accumulation of secretions in the resultant subcuticular space was not observed.

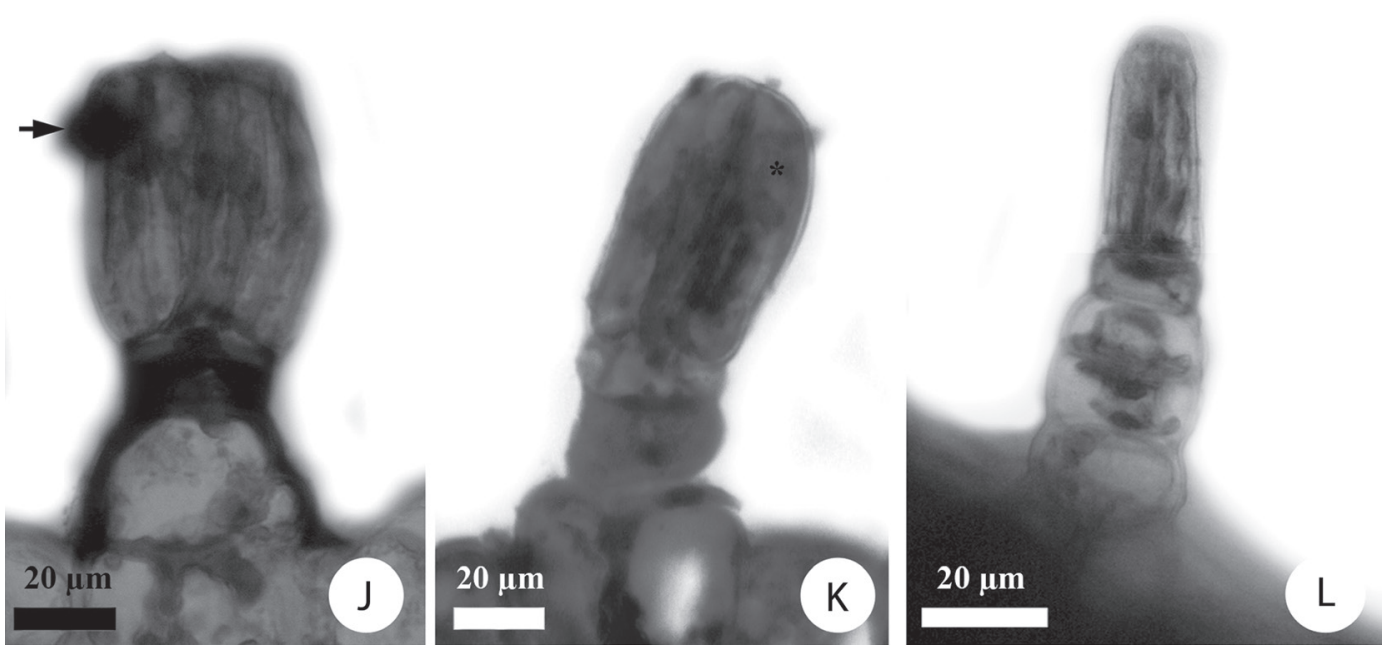

Fig. 2. Histochemical tests on glandular trichomes of calyx of Adenocalymma magnificum in secretory stage. A. Lipid substances identified by Sudan Black B. B. Acidic lipids on secretory cells. C. Phenolic compounds on the secretory head, evidenced by ferric chloride. 


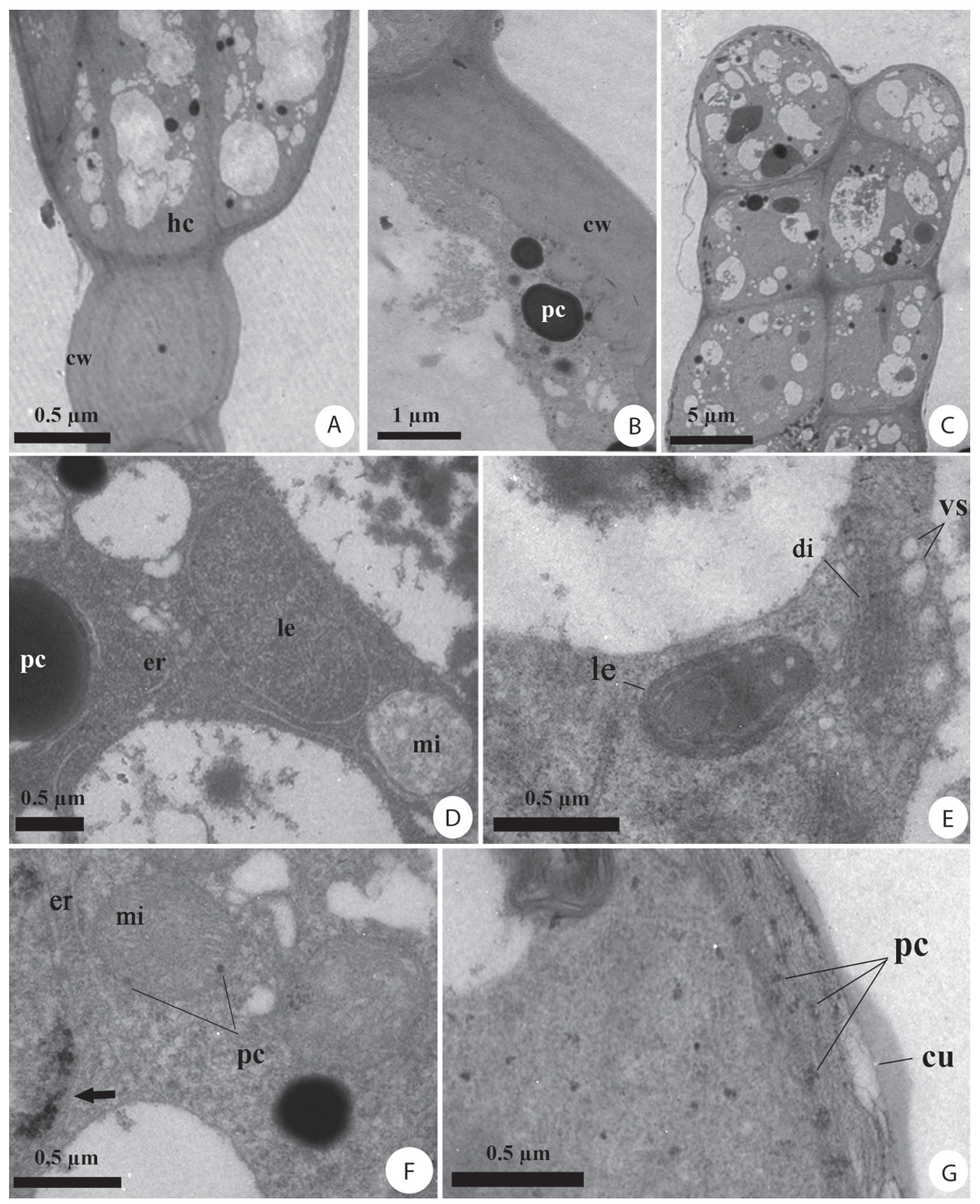

Fig. 3. Ultrastructure of the capitate glandular trichomes of Adenocalymma magnificum in secretory stage. A - B. Peduncle cell. A. Overview, note the thick wall. B. Thick wall and electron dense droplets. C - G. Secretory head cells. C. Overview of the cells which constitute the trichome head. D. Detail, demonstrating the most common organelles in the trichome: smooth endoplasmic reticulum, leucoplasts and mitochondria; note endoplasmic reticulum involving the leucoplast. E. Vesicles being produced next to dictyosomes and leucoplasts with a few inner membranes. F. Smooth endoplasmic reticulum producing phenolic compounds (arrow). G. Phenolic compounds crossing the cell wall to be released; partial distension of the cuticle. Abbreviations: cu, cuticle; cw, cell wall; di, dictyosomes; er, smooth endoplasmic reticulum; hc, head cells; le, leucoplast; mi, mitochondria; pc, phenolic compound; va, vacuole; vs, vesicles. 


\section{DISCUSSION}

In this study, the glandular trichomes of A. magnificum were analyzed using micromorphological data in an ontogenetic sequence to better understand the glandular activities occurring in this trichome. The glandular trichome consists of a long peduncle composed of two to nine cells and a multicellular secretory head, columnar shaped, arranged in a disk.

A considerable diversity of capitate glandular trichomes, varying in peduncle size and secretory head cell shape and number, has been detected in taxa related to the Order Lamiales, belonging to Bignoniaceae (Ascensão, Marques, \& Pais, 1995; Combrinck, Du Plooy, McCrindle, \& Botha, 2007; Jurišić Grubešić, Vladimir-Knežević, Kremer, Kalodera, \& Vuković, 2007). The glandular trichome morphological diversity, according to Ascensão, Mota, and Castro (1999), is associated with distinct secretion processes and distinct exudate chemical composition. On the capitate glandular trichome of $A$. magnificum, the histochemical analysis indicated the presence of lipophilic substances in the secretion contained in the trichome head.

In the ultrastructural analysis, the impregnation of the anticlinal surfaces of the peduncle cell by lipid compounds was observed. They appear to prevent apoplastic transport and block the secretion reflux, making the extrusion easier; the same was described for other secretory structures (Fahn, 2000; Paiva, 2009; Paiva, \& Martins, 2011).

The presence of smooth endoplasmic reticulum, plastids with strongly electron-dense stroma, developed dictyosomes and large quantity of lipid drops along the cytoplasm are evidence of a predominant lipid secretion (Fahn, 1979; Machado, Gregório, \& Guimarães, 2006; Sacchetti et al., 1999). This ultrastructural observation is corroborated by the positive histochemical test for Sudan black B.

The secretory cells possess a prominent smooth endoplasmic reticulum, several leucoplasts and mitochondria. These three organelles are the predominant ones and are involved in the production of osmiophilic substances. The significant presence of smooth endoplasmic reticulum and plastids indicate lipid production; however, little is known about mitochondria also being involved in this process. In the capitate glandular trichomes of the A. magnificum calyx, electron-dense drops were observed inside this structure, which suggests that the production is partially performed by the mitochondria as well. This association is unusual but was previously confirmed in oil glands of Citrus (Thomson, Platt-Aloia, \& Endress, 1976) and also in terpenoid biosynthesis (Croteau, Kutchan, \& Lewis, 2000).

According to Schmid and Ohlrogge (2002), the mitochondria are probably the most detailed organelles investigated regarding lipid metabolism. Their ability to synthesize phosphatidylglycerol and cardiolipin is well-known. Mitochondria were also demonstrated as synthesizing low levels of fatty acids originating from malonate.

The capitate glandular trichomes of $A$. magnificum may be involved in the plant's chemical defense against insects (Favorito, 2009). For a final conclusion regarding herbivory or other plant-environment interactions, more studies are required to relate density patterns of capitate glandular trichomes on adaxial surface of A. magnificum calyx and the secretion amount.

The study of ontogeny, morphology and ultrastructure of the capitate glandular trichomes of the calyx adaxial surface of $A$. magnificum demonstrated that the production of lipophilic substances is important for this plant, possibly offering efficient protection against herbivores.

\section{ACKNOWLEDGMENTS}

This work was carried out during the first author master's program at Universidade Federal Rural da Amazônia/Museu Paraense Emílio Goeldi, Laboratório de Anatomia vegetal. 


\section{RESUMEN}

Tricomas calicinales de Adenocalymma magnificum (Bignoniaceae) que producen sustancias lipofílicas: aspectos ultraestructurales y funcionales. Las estructuras que secretan lípidos y compuestos fenólicos estan frecuentemente asociadas a la protección y desarrollo de órganos que protegen contra la desecación, además de la protección que estas proporcionan contra el ataque de animales. Los tricomas capitados de Adenocalymma magnificum son estructuras de este tipo. Para comprender las actividades glandulares que ocurren en estos tricomas es necesario estudiar su ontogenia, estructura, ultraestructura y aspectos histoquímicos. La interpretación de sus funciones ecológicas o historia evolutiva es compleja, y pocos son los estudios que se enfocan en los tricomas calicinales no secretores de néctar. Las muestras del cáliz floral en antesis y botones florales en diferentes estadios de desarrollo fueron fijadas y procesadas de acuerdo con los métodos para microscopia de luz y electrónicos. Los tricomas de A. magnificum están aleatoriamente distribuidos en toda la extensión de la superficie interna del cáliz, también observados en los botones florales. Estos tricomas son glandulares capitados, compuestos de un pedúnculo largo que posee hasta nueve células y una cabeza secretora multicelular, con células en columnares dispuestas en disco. La célula del collar, que esta sobre las células de la cabeza secretora, se divide anticlinalmente organizándose lado a lado con las células madre. Con el crecimiento de los tricomas, estos mismos se curvan y algunos quedan adpresos al cáliz. Las pruebas histoquímicas indicaron que las células de la cabeza secretora producen sustancias lipídicas, lípidos ácidos y compuestos fenólicos. En la cabeza secretora la vacuoma esta dispersa y posee abundante retículo endoplasmático liso y leucoplastos, los cuales son organelos involucrados en el proceso de producción de sustancias osmiofílicas. En algunas regiones de las células secretoras la distensión de la cutícula fue observada, sin embargo, no fue verificada la acumulación de secreción. Este trabajo describe por primera vez el origen, desarrollo y proceso de secreción de tricomas calicinales de $A$. magnificum, mostrando que la producción de substancias lipofílicas es importante para esta especie, ofreciendo posiblemente protección contra la herbivoría.

Palabras clave: Adenocalymma, tricomas capitados, lípidos, compuestos fenólicos.

\section{REFERENCES}

Ascensão, L., Marques, N., \& Pais, M. (1995). Glandular trichomes on vegetative and reproductive organs of Leonotis leonurus (Lamiaceae). Annals of Botany, 75, 619-626.

Ascensão, L., Mota, L., \& Castro, M. M. (1999). Glandular trichomes on the leaves and flowers of Plectranthus ornatus: morphology, distribution and histochemistry. Annals of Botany, 84, 437-447.

Ascensão, L., \& Pais, M. S. S. (1987). Glandular Trichomes of Artemisia campestris (ssp. Maritima): ontogeny and histochemistry of the secretory product. Botanical Gazette, 148, 221-227.

Bottega, S., \& Corsi, G. (2000). Structure, secretion and possible functions of calyx glandular hairs of Rosmarinus officinalis L. (Labiatae). Botanical Journal of the Linnean Society, 132, 325-335.

Cain, A. J. (1947). The use of Nile blue in the examination of lipoids. Quarterly Journal of Microscopical Science, $88,383-392$.

Castro, M. A., Vega, A. S., \& Múlgura, M. E. (2001). Structure and ultrastructure of leaf and calyx glands in Galphimia brasiliensis (Malpighiaceae). American Journal of Botany, 88, 1935-1944.

Combrinck, S., Du Plooy, G. W., McCrindle, R. I., \& Botha, B. M. (2007). Morphology and histochemistry of the glandular trichomes of Lippia scaberrima (Verbenaceae). Annal of Botany, 99, 1111-1119.

Croteau, R., Kutchan, T. M., \& Lewis, N. G. (2000). Natural Products (Secondary Metabolites). In B. Buchanan, W. Gruissem, \& R. Jones (Eds.), Biochemistry \& Molecular Biology of Plants (pp. 1250-1318). Rockville: American Society of Plant Physiologists.

Fahn, A. (1979). Secretory tissues in plants. London: Academic Press.

Fahn, A. (2000). Structure and function of secretory cells. Advances in Botanical Research, 31, 37-75.

Favorito, S. (2009). Tricomas secretores de Lippia stachyoides Cham. (Verbenaceae): estrutura, ontogênese e secreção (Master thesis). Universidade Estadual Paulista. Retrieved from http://base.repositorio.unesp.br/ bitstream/handle/11449/88132/favorito_s_me_botib. pdf? sequence $=1$ \&isAllowed $=\mathrm{y}$

Gerlach, D. (1984). Botanische Mikrotechnik. Stuttgart: Georg Thieme.

Hayat, M. A. (1972). Basic electron microscopy techniques. New York: VanNostrand Reinhold.

Johansen, D. A. (1940). Plant microtechnique. New York: McGraw-Hill Book Company Inc.

Jurišić Grubešić, R., Vladimir-Knežević, S., Kremer, D., Kalodera, Z., \& Vuković, J. (2007). Trichome micromorphology in Teucrium (Lamiaceae) species growing in Croatia. Biologia, 62, 148-156.

Machado, S. R., Gregório, E. A., \& Guimarães, E. (2006). Ovary peltate trichomes of Zeyheria montana (Bignoniaceae): developmental ultrastructure and secretion in relation to function. Annals of Botany, 97, 357-369.

McManus, J. F. A. (1948). Histological and histochemical uses of periodic acid. Stain Technology, 23, 99-108. 
Moura, M. Z. D., Isaias, R. M. S., \& Soares, G. L. G. (2005). Ontogenesis of internal secretory cells in leaves of Lantana camara (Verbenaceae). Botanical Journal of the Linnean Society, 148, 427-431.

Paiva, E. A. S., \& Martins, L. C. (2011). Calycinal trichomes in Ipomoea cairica (Convolvulaceae): ontogenesis, structure and functional aspects. Australian Journal of Botany, 59, 91-98.

Paiva, E. A. S. (2009). Ultrastructure and post-floral secretion of the pericarpial nectaries of Erythrina speciosa (Fabaceae). Annals of Botany, 104, 937-44.

Pearse, A. G. E. (1980). Histochemistry, Theoretical and Applied: Preparative and optical technology. London: Churchill Livingstone.

Reynolds, E. S. (1963). The use of lead citrate at high $\mathrm{pH}$ as an electron-opaque stain in electron microscopy. Journal of Cell Biology, 17, 208-212.

Rivera, G. L. (2000a). Nuptial nectary structure of Bignoniaceae of Argentina. Darwiniana, 38, 227-239.

Rivera, G. L. (2000b). Nectarios extranupciales florales en especies de Bignoniaceae de Argentina. Darwiniana, $38,1-10$.

Robards, A. W. (1978). An introduction to techniques for scanning electron microscopy of plant cells. In J. L. Hall (Ed.), Electron Microscopy and Cytochemistry of Plant Cells (pp. 343-444). New York: Elsevier.

Roland, J. C. (1978). General preparations and staining of thin sections. In J. L. Hall (Ed.), Electron Microscopy and Cytochemistry of Plant Cells (pp. 1-63). New York: Elsevier.

Sacchetti, G., Romagnoli, C., Nicoletti, M., Di Fabio, A., Bruni, A., \& Poli, F. (1999). Glandular Trichomes of Calceolaria adscendens Lidl. (Scrophulariaceae): Histochemistry, Development and Ultrastructure. Annals of Botany, 83, 87-92.

Schmid, K. M., \& Ohlrogge, J. B. (2002). Lipid metabolism in plants. In D. E. Vance, \& J. E. Vance (Eds.), Biochemistry of Lipids, Lipoproteins and Membranes (pp. 93-126). Amsterdam: Elsevier.

Seibert, R. J. (1948). The Use of Glands in a Taxonomic Consideration of the Family Bignoniaceae. Annals of the Missouri Botanical Garden, 35, 123-137.

Silva, E. M. J., \& Machado, S. R. (1999). Estrutura e desenvolvimento dos tricomas secretores em folhas de Piper regnellii (Miq.) C. DC. var. regnellii (Piperaceae). Brazilian Journal of Botany, 22, 117-124.

Simões, A. O., Castro, M. M., \& Kinoshita, L. S. (2006). Calycine colleters of seven species of Apocynaceae (Apocynoideae) from Brazil. Botanical Journal of the Linnean Society, 152, 387-398.

Solereder, H. (1908). Systematic Anatomy of the Dicotyledons. Oxford: Clarendon Press.

Subramanian, R. B., \& Inamdar, J. A. (1985). Occurrence, Structure, Ontogeny and Biology of Nectaries in Kigelia pinnata DC. Botanical Magazine, 98, 67-73.

Subramanian, R. B., \& Inamdar, J. A. (1989). The structure, secretion and biology of nectaries in Tecomaria capensis Thunb (Bignoniaceae). Phytomorphology, 39, 69-74.

Thomson, W. M., Platt-Aloia, K. A., \& Endress, A. G. (1976). Ultrastructure of Oil Gland Development in the Leaf of Citrus sinensis L. Botanical Gazette, 137, 330-340. 